УДК 316.347

\title{
Some Aspects of Social Communication Phenomenon Evolution
}

\section{B. R. Mogilevich}

Bronislava R. Mogilevich, https://orcid.org/0000-0002-4986-9183, Saratov State University, 83 Astrakhanskaya St., Saratov 410012, Russia, mogilevich@sgu.ru

The article is devoted to sociological reflection of social communication and channels typology. The chronotypes of communication process - genetic, psychological, and social are considered. The typology characteristics of communication processes in diachronic and synchronic aspects are presented. It is shown that communication typology reflects the humankind evolution, an individual being a social communication subject. The characteristics of social communication as a process of exchanging meanings in social space and time are given. The goals and social actions in the course of social communication are thoroughly investigated. Communicator's social actions at micro, midi, and macro levels of social communication are presented. The stages of communication channels, natural and artificial ones, as communicative mechanisms are notified. Particular attention is paid to the Internet as the communication channel of postindustrial information society. In conclusion, the dynamic nature of communication and its channels is stressed.

Keywords: social communication, social actions, micro midi and macro levels, communication channels, internet technologies.

Некоторые аспекты эволюции феномена социальной коммуникации

\section{Б. Р. Могилевич}

Могилевич Бронислава Рафаиловна, доктор социологических наук, профессор кафедры английского языка для гуманитарных направлений и специальностей, Саратовский национальный исследовательский государственный университет имени Н. Г. Чернышевского, mogilevich@sgu.ru

Статья посвящена социологической рефлексии типологии социальной коммуникации. Рассмотрены хронотопы коммуникативных процессов - генетический, психологический и социальный. Представлены типологические характеристики коммуникативных процессов в диахроническом и синхроническом аспектах. Показано, что типология коммуникации отражает эволюцию развития индивида как субъекта социальной коммуникации. Даны характеристики социальной коммуникации как процесса обмена смыслами в социальном пространстве и времени. Подробно представлены цели и социальные действия в процессе социальной коммуникации. Представлены социальные действия коммуникантов на микро-, миди- и макроуровнях коммуникации. Обозначены этапы становления коммуникационных каналов как механизмов социальной коммуникации, естественных и искусственных и их функций. Особое внимание уделено Интернету как коммуникационному каналу постиндустриального информационного общества. В заключение подчеркнут динамический характер эволюции социальной коммуникации и коммуникационных каналов.

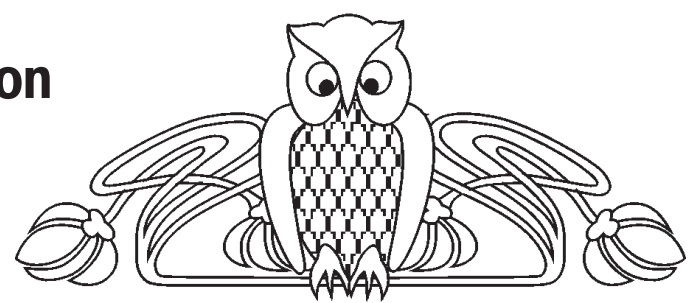

Ключевые слова: социальная коммуникация, социальное действие, микро-, миди- и макроуровень, коммуникационные каналы, интернет-технологии.

DOI: https://doi.org/10.18500/1818-9601-2020-20-1-23-26

Communication by its nature is the process of exchanging information leading to mutual understanding and activity, the social relations between society members being realized in its course. In its turn, communication may be considered from various points of view, the main ones are: the movement of material objects in geometrical space and astronomic time; the movement of ideal objects (meanings) in spiritual (virtual) space and time. The development of IT technologies, especially the emergence of the Internet, made it possible to consider virtual communication in virtual space and time as the movement of meanings. Chronotypes (space-time characteristics) define communication typology (Fig. 1). Thus, genetic chronotype as genetic programs in biological time and space implements material communication (transport, energy, population migration, and so on); psychological communication reflects spiritual individuals' characteristics filled with meanings, implemented on interpersonal level. As for social chronotype, it is presented as the movement of aggregated meanings obtained and developed in the course of social interaction.

An individual serves as a link between genetic, psychological and social communication types. For example, genetic communication supplies an individual with a social communication mechanism as neuro psychological, anatomical, articulation and speech abilities, aimed at establishing and maintaining social communication [1].

Psychological communication is formed as individuals' socialization when they take on various social roles, an addresser and an addressee in particular. Social communication is formed on the basis of genetic and psychological types, simultaneously with their formation and functioning. Thus, mental and speech organs and abilities are genetically inherited as they emerged and developed due to their relevance and evolution, whereas individuals' psychological development is influenced by their socialization levels. Thus, social communication represents the exchange of meanings, but not material properties. The thing is, that meanings exist not only in genetic, psychological and social types of communication, but at the same time represent material and cultural values, as well as natural phenomena. Meanings can be considered as a variety of social 


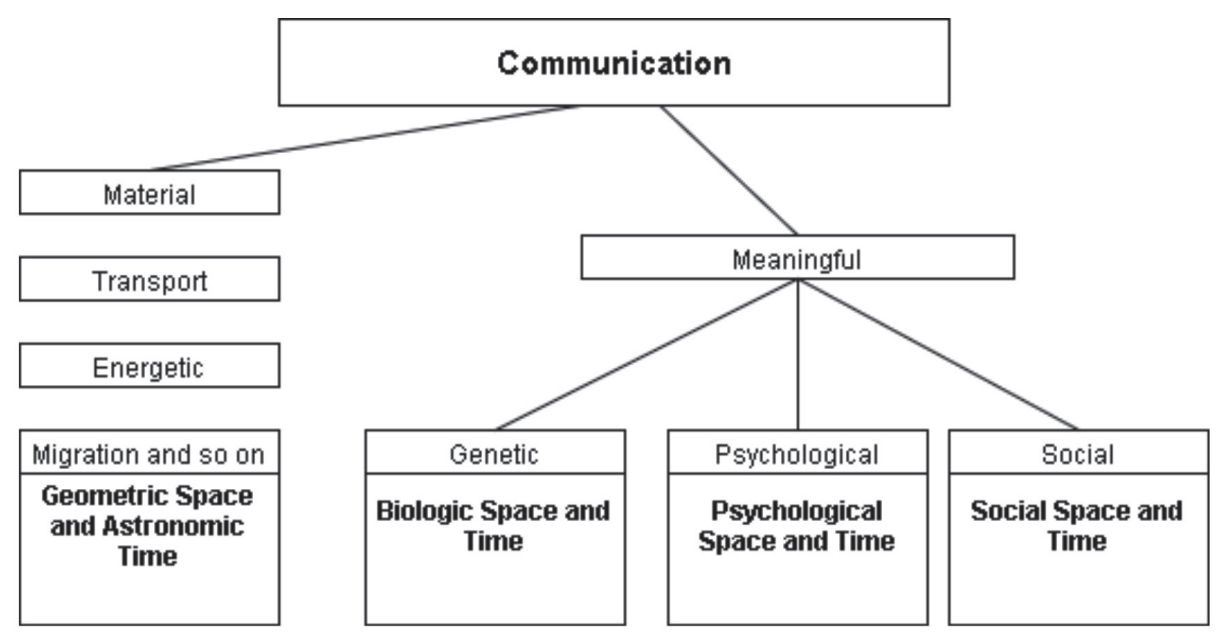

Fig. 1. Communication Typology [1, p. 31]

relations in the course of personal, groups', nations', states' and civilization' interactions. The meanings propagate in social space in the course of social interaction. Social space correlates with social time existing in society members' feelings and senses. In the course of time social senses and feelings cease to be actual and significant due to social life intensity. For example, social time in the period of wars and revolutions differs greatly from that one in peace. In the course of social communication an individual pursues the following goals: cognitive (propagating and acquiring information); motivating (stimulating actions); expressive (expressing and acquiring emotions) [2].

In the course of social communication (interaction of meanings) people perform three kinds of social actions. Imitation - an addressee accepts an addresser's meanings, imitation by itself represents the channel of propagation and implementing new meanings as new ideas and trends. It is due to imitation that traditions and customs inheritance takes place. Dialog - a subject-subject interaction, when partners are equal and unified from socio-psychological point of view. Management takes place in the case of subject-object relations, when an addresser occupies a superior position to an addressee. Moreover, an addresser considers an addressee as a means of achieving certain goals. These three kinds of social actions can complement each other or unite but one of them dominates.

Social communication functions of three levels, where all kinds of social actions are presented. The first level - micro communication takes place when both partners are active addressers and active addressees. The former performs imitation and dialog, the latter is engaged in dialog or management. The partners are presented by individuals, social groups, and society as a whole. Micro communication content is always conditioned by communicators' social attribution, and they perform: exchanging of ideas and points of view (a dialog), instructing subordi- nates (management), copying actions and patterns (imitation). In the case of groups' interaction micro communication can function in the following forms: references (imitation but not by separate individuals but by social groups), management (administrating and leadership in a group or an organization), socialization (mastering official norms, ideals, and social values), authorization (despotic management of social and ethnic groups) [3].

Midi communication level is based on three forms of social communication - fashion (transmitting material forms, behavioral norms, ideas, possessing emotional positive impact and attraction for social groups); negotiations, in the form of multi subjective dialogs between social groups; group hierarchy (solders and commanders in the army, a rector and professors at universities and so on) where all interrelations are strictly regulated and adaptation to them is often accompanied by conflicts between the representatives of various nations, cultures and religions (for example, the exchange of meanings influencing spiritual and ideological life of society members - G. Galileo's, C. Marx's, and Z. Freud's theories).

Macro communication takes place in the form of interaction between states, cultures, religions and civilizations, and incorporates the following forms: borrowing achievements as macro communication imitation; cultural interaction under equal macro cultural dialog; information aggression. $\mathrm{T}$ history of cultural contacts between Russia and Europe is of great interest and can serve as an example. The Christianization of Russia at the end of the X century was the imitation of this event in Byzantine. By the middle of the XIV century Russian orthodox church got free from Constantinople domination, and Moscow state acquired political independence. Ivan IV (the Terrible) became an equal partner between European monarchs and the cultural dialog on the macro communication level between Russian and European countries was established and main- 
tained. But in the twentieth century, soon after the end of World War II, information aggression on the macro cultural level took place - the so called "Cold War" between the USSR and its eastern European allies on the one side, and the USA and the countries of western Europe on the other side.

Social communication is distributed by means of communication channels (Fig. 2). Their number constantly increases according to the stages of humankind development - from primitive to post industrial stages. Natural communication channels emerge in the course of anthropogenesis while artificial ones were constructed by human beings themselves. Natural communication channels are based on humans' attributed mechanisms for transferring meanings - verbal and nonverbal ones. Nonverbal mechanisms are widely and actively used at all levels of communication to express emotions and are presented by paraverbal communication channels. Verbal communication is inherent to humans only and the need for artificial communication channels emerges in the cases when an addresser and an addressee want to transfer social meanings to each other but are separated by social time and space. Two artificial communication channels came into being almost simultaneously and are presented as iconic documents (graphics and pictures on caves' walls), and symbolic documents (talismans, idols, amulets). They performed the following functions: educational as experience transfer from one generation to another, intellectual aiming at development mental abstract activity; aesthetic as creating the sense of the beautiful [4, p. 113-116].

Communication channels provide contacts (virtual or real) for distributing information in the form of symbols, natural or artificial languages, codes, and electronic devices. It is noteworthy that communication activity makes it possible to distribute social meanings either in material or virtual space. According to McCluen, human progress is determined by communication channels development. The evolution can be presented as follows: archeocultural epoch is characterized by such communication channel as articulated speech; paleolithic gave rise to writing; neocultural epoch used bookprinting and individual reading; modern epoch of postmodernism and information society uses electronic devices as communication channels [5].

It is quite appropriate to point out that evolution of social communication, in general, and communication channels, in particular, gave rise to emerging new communication devices to adequately correspond to modern social reality. The concept of postindustrial information society reflects the appearance of new communication channels - electronic devices and the invention of personal computers and subsequent mass computerization caused communication emancipation. Two main reasons of establishing information society - computerization and globalization stressed the significance of information exchange for civilization progress. It is known that information phenomenon acquired special importance even in the Medieval Times. In the course of time it is information that determined generation, evaluation, and transfer of communication information. Postindustrial society is characterized by the phenomenon of information power due to its universal nature and deep integrity in all spheres of humans' lives [6]. New communication channels are presented by the Internet technologies, they exist in the form of various electronic servers (email, electronic encyclopedias, social websites, and so on). The most famous of them are Odnoklassniki, Facebook, YouTube, Telegram, etc. They have become an integral part of everyday life and changed humans' status since the access to websites is every human being's personal right. Moreover, the Internet as a modern communication channel contributes to widening socialization and unification of humans' mutual activity, defending human rights, mutual environmental actions and charity. The number of Internet users is constantly increasing, for example, according to National Scientific Fund prognosis (the USA) by 2020 the number of Internet users will reach 5 billion people [7]. Modern communication channels provide humankind with various advantages, such as access to worldwide knowledge, democratization of interpersonal relations, constant receipt

\section{Natural Channels}

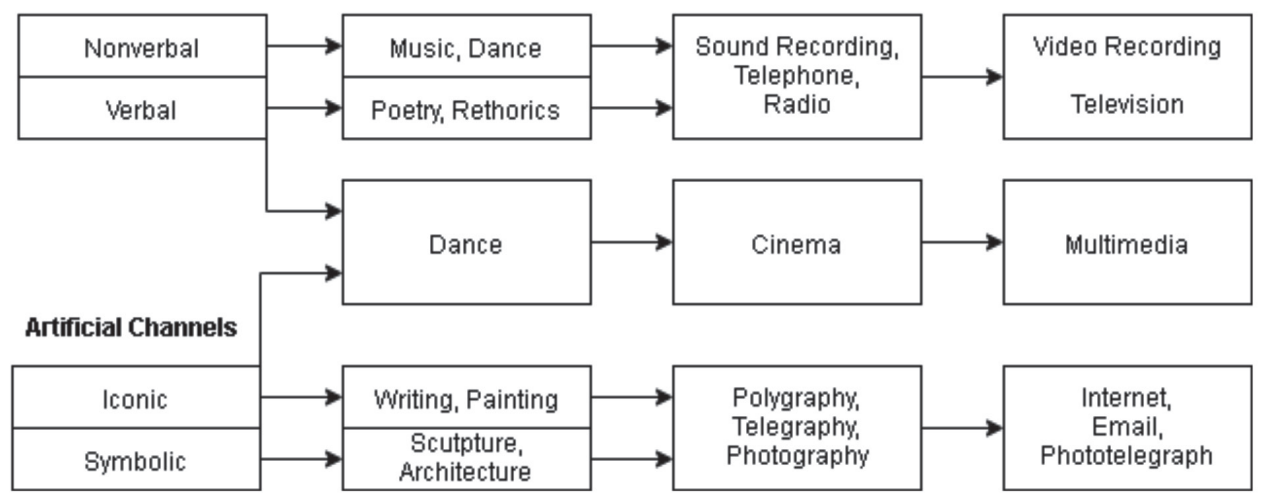

Fig. 2. The Evolution of Communication Channels [1, p. 86] 
of information "here" and "now", and improvement of life quality.

Thus, social communication is characterized as a complex, multi level and multi aspect process of exchanging social meanings in social time and space. This phenomenon possesses heterogeneous structure and unique forms of presentation at various levels of society development. Without taking into account these peculiarities it is impossible to comprehend the specific features of contemporary stage of social communication. Social communication is conditioned, in its turn, by appearance and evolution of communication channels which contribute to widening and maintaining social communication of humankind.

\section{References}

1 Sokolov A. V. Obschaya teoriya social'noi kommunikatsii [General History of Social Communication]. St. Petersburg, Mihajlova V. A. Publ., 2002. 461 p. (in Russian).

2 Pavilenis R. I. Problema smysla. Sovremennyi logiko- smyslovoi analiz yazyka [The Problem of Meaning. Contemporary Logic-Meaningful Analysis of Language]. Moscow, Mysl' Publ., 1983. 286 p. (in Russian).

3 Borev V. Yu. Kul tura i massovaia kommunikatsiya [Culture and Mass Communication]. Moscow, Nauka Publ., 1986. 303 p. (in Russian).

4 Nazarchuk A. V. Teoriya kommunikatsii v sovremennoi filosofii [The Theory of Communication in Modern Philosophy]. Moscow, Progress-Traditsiya Publ., 2009. 320 p. (in Russian).

5 Maklyuen M. Galaktika Guttenberga. Stanovleniye cheloveka pechatayuschego [The Gutenberg Galaxy: The Making of Typographic Man]. Moscow, Akademicheskiy proekt Publ., 2013. 496 p. (in Russian).

6 Castells M. Informatsionnaia epokha: ekonomika, obschestvo, kul tura [Information Era: Economics, Society, Culture.]. Moscow, GU VShE Publ., 2000. 219 p. (in Russian)

7 Romanov O. V. Filosofiya Interneta (genezis i sintez fundamental'nykh idey) [The Philosophy of the Internet (Genesis and Synthesis of the Fundumental Ideas)]. Samara, Perspektiva Publ., 2003. 174 p. (in Russian).

\section{Образец для цитирования:}

Mogilevich B. R. Some Aspects of Social Communication Phenomenon Evolution [Могилевич Б. Р. Некоторые аспекты эволюции феномена социальной коммуникации] // Изв. Сарат. ун-та. Нов. сер. Сер. Социология. Политология. 2020. Т. 20, вып. 1. C. 23-26. DOI: https://doi.org/10.18500/1818-9601-2020-20-1-23-26

\section{Cite this article as:}

Mogilevich B. R. Some Aspects of Social Communication Phenomenon Evolution. Izv. Saratov Univ. (N. S.), Ser. Sociology. Politology, 2020, vol. 20, iss. 1, pp. 23-26. DOI: https://doi.org/10.18500/1818-9601-2020-20-1-23-26 